\title{
Lack of association of hepatitis C virus (HCV) antibodies and juvenile onset systemic lupus erythematosus (jSLE)
}

\author{
Cláudia Goldenstein-Schainberg*, Ana P Nascimento, André LS Hayata, Eloisa Bonfá \\ From 18th Pediatric Rheumatology European Society (PReS) Congress \\ Bruges, Belgium. 14-18 September 2011
}

\section{Background}

The association between viral infections such as hepatitis $\mathrm{C}$ virus (HCV) and autoimmunity has been proposed. Antibodies against HCV have been demonstrated in sera from up to $13 \%$ adult patients with SLE, however data regarding juvenile onset SLE (jSLE) is lacking despite potential increased risk factors associated.

\section{Aim}

To determine the prevalence and possible association of HCV infection and jSLE.

Methods: We evaluated 40 jSLE patients (according to ACR criteria); mean age $=19 \pm 4.4$ years and mean disease duration $=6 \pm 3.2$ years; 34 females, 6 males. Twenty healthy children and 20 rheumatic fever patients matched for age and sex were included as controls. All subjects were interviewed in order to search for risk factors for $\mathrm{HCV}$ infection including use of endovenous drugs, blood products transfusions, promiscuous sexual activity, previous hospitalizations and/or invasive diagnostic or therapeutic procedures. Serum samples were tested for ANAs by standard techniques and for anti-HCV antibodies using a high sensitive third generation microparticle enzyme immunoassay (AxSYM HCV version 3.0, Abbott Lab.).

\section{Results}

Thirty-six (90\%) jSLE patients were under immunossupressive therapy; 47 hospitalizations and 19 invasive procedures were required by jSLE subjects contrasting to only 5 hospitalizations and 5 invasive procedures by the control group. ANA titers were elevated in all $40 \mathrm{jSLE}$

\footnotetext{
* Correspondence: cgs@usp.br

Rheumatology Division, Faculdade de Medicina da Universidade de São Paulo, São Paulo, SP, Brazil
}

sera and negative in all controls. Remarkably only one $(2.5 \%)$ jSLE sera was anti-HCV positive compared to all uniformly negative control sera.

\section{Conclusion}

Contrary to adult onset SLE, the low prevalence of anti$\mathrm{HCV}$ antibodies in sera from jSLE patients suggests lack of association of HCV infection and jSLE.

Published: 14 September 2011

doi:10.1186/1546-0096-9-S1-P268

Cite this article as: Goldenstein-Schainberg et al.: Lack of association of hepatitis $C$ virus (HCV) antibodies and juvenile onset systemic lupus erythematosus (jSLE). Pediatric Rheumatology 2011 9(Suppl 1):P268.

Submit your next manuscript to BioMed Central and take full advantage of:

- Convenient online submission

- Thorough peer review

- No space constraints or color figure charges

- Immediate publication on acceptance

- Inclusion in PubMed, CAS, Scopus and Google Scholar

- Research which is freely available for redistribution

\section{( Biomed Central}

(c) 2011 Goldenstein-Schainberg et al; licensee BioMed Central Ltd. This is an open access article distributed under the terms of the Creative Commons Attribution License (http://creativecommons.org/licenses/by/2.0), which permits unrestricted use, distribution, and reproduction in any medium, provided the original work is properly cited. 